\title{
Emergent systematicity in Tây Bồi (Vietnamese Pidgin French)
}

\author{
Oliver Mayeux, Trinity College, Cambridge \\ ofm23 at cam dot ac dot uk
}

\section{(i) Are pidgins 'structureless'?}

-Pidgins traditionally characterized as 'fluid, structureless, and probably macaronic.'[1]. The pidgin-to-creole model assumes grammatical systematicity only emerges post-creolization, i.e. after pidgin acquired as L1.

-However, data from Tây Bồi (Vietnamese Pidgin French; VPF) suggest an emergent system without creolization, i.e. in adult L2 acquirers. The analysis here is a work-in-progress and feedback is very much appreciated.

\section{(ii) Vietnamese Pidgin French}

- Vietnam endured six decades of French colonization, which saw the acquisition of French (tây) by adolescent male indentured workers (bồi).[2]

-Resultant pidgin, VPF, never creolized. No longer spoken. Records of VPF consist of descriptions by a handful of authors. [3-7]

-VPF exhibited widespread variation between speakers and within the same speaker. But such variation was likely not completely unstructured at a community level, with both diastratic and diatopic variation indicated in the data.

\section{(iii) Morphological reanalysis}

-Reinecke: "Since many common indicative and imperative forms as well as the vast majority of infinitives end in /e/, [VPF] speakers 'hear' /e/ as the appropriate ending for some verbs not derived from the first conjugation infinitives." [5] -Largest class of French verbs ends /e/ in infinitive (1); unlike other classes (2-4).
( 1) Fr. /parle/ 'speak.IN F'
( 2) Fr. /vãdr/ 'sell.ın F'
( 3) Fr. /vənir/ 'come.IN F'
(4) Fr. /avwar/ 'have.IN F'

- /e/ also encodes IPFV and IM PF for all verb classes.

( 5) Fr. /parle/ 'speak.IPFV; speak.IM P F'

( 6) Fr. /vãde/ 'sell.IPF V; sell.IM PF'

( 7) Fr. /vəne/ 'sell.IPF V; sell.IM PF'

( 8) Fr. /ave/ 'have.IPFV; have.IMPF'

-Forms ending /e/ are selected from French intake as the VPF verb regardless of TMA/finiteness. VPF verbs have a single form in all contexts. [5]

(9) VPF /pale/ 'speak'

(10) VPF /vajde/ 'sell'

(11) VPF /ave/ 'have'

(12) VPF /vəne/ 'come'

-N.B. Not all VPF speakers had this system![5]

-For VPF speakers with this system, the high-frequency French verb ending /e/ in the intake was overgeneralized as a marker of verb status; possibly categorical feature [V].

\section{(iv) Morphological extension}

-VPF speakers extended /e/ to Vietnamese VPs to derive novel verbs. [6]

(13) VPF/de.bi.e/ 'take off; take away' $<$ Vn. /Rdił ve J/ đi về 'return' + /e/

(14) VPF /kwat.e/ 'fan oneself' $<$ Vn. /kwət' 1 ?/ quat 'fan' + /e/

(15) VPF /ka.duj.e/ 'hit with bamboo' $<$ ? Vn. /kwət`^ zəj-1/ quất roi 'flog' + /e/

\section{(v) Systematicity in pidgins}

-Can a pidgin be 'structureless' from a generative perspective? -Pidgin speakers systematize intake, even without creolization. VPF speakers assign categorical feature [V] by overgeneralizing across French morphology.

- Feature assignment is emergent in part through the application of domain-general cognitive factors (Chomsky's Factor 3[8]), viz. acquirers' inherent tendency to Maximise Minimal Means by overgeneralizing across the intake, even in adult acquirers. [9]

-The latest generative theory of creolization by Aboh \& DeGraff [10] has so far concentrated on Factors 1 \& 2, i.e. Universal Grammar, and Primary Linguistic Data. Combining these insights with the Maximise Minimal Means model may lead to deeper understanding of Factor 3 in the formation of new languages.

-Further work: Detailed syntactic analysis of VPF data; application to creole data; theoretical and empirical distinction between L1 \& L2 acquirers as applied to pidginization/creolization.

[1] Bickerton, D. 1999. How to acquire language without positive evidence: What acquisitionists can learn from creoles. In Michel DeGraff (ed.), Language creation and language change, 4974. Cambridge, M.A.: MIT.

[2] Love, S. 2000. French and Tây Bò̀i in Vietnam: A study of language policy, practice and perception.

University of Adelaide MA dissertation.

[3] Nguyê̂n, Đăng Liêm. 1979. Cases and verbs in Pidgin French (Tây Bồi) in Vietnam. In Papers in Pidgin and Creole Linguistics, Vol. 2, 217-246. Canberra: Australian National University.

[4] Philips, John Seward. 1975. Vietnamese contact French: Acquisitional variation in a language

contact situation. Bloomington, IN: Indiana University dissertation.

[5] Reinecke, John E. 1968. Tây Bồi: Notes on the Pidgin French of Vietnam. In Dell Hymes (ed.), Pidginization and creolization of languages. Cambridge: Cambridge University Press.

[6] Schuchardt, Hugo. 1888. Ueber das Annamito-Französische. Kreolische Studien VIII.

[7] Stageberg, Norman C. 1956. Pidgin French Grammar: A Sketch. The Modern Language Journal

40(4). 167.

[8] Chomsky, N. 2005. Three Factors in Language Design. Linguistic Inquiry 36(1). 1-22. [9] Biberauer, T. 2019. Children always go beyond the intake: The Maximise Minimal Means perspective. Theoretical Linguistics 45(3-4). 211-224.

[10] Aboh, Enoch \& Michel DeGraff. 2016. A Null Theory of Creole Formation Based on Universal

Grammar. The Oxford Handbook of Universal Grammar. 